Gadjah Mada International Journal of Business

Vol. 14, No. 1 (January - April 2012): 61 - 75

\title{
Is Earnings Management Informational or Opportunistic? Evidence from ASEANCountries
}

\author{
Dewi Kusuma Wardani \\ Universitas Sarjanawiyata Tamansiswa, Indonesia \\ Indra Wijaya Kusuma \\ Faculty of Economics and Business, Universitas Gadjah Mada, Indonesia
}

\begin{abstract}
This study explores the informational and opportunistic characteristics of earnings management in ASEAN countries. Earnings management has an impact on the profitability of the companies. A positive relation between earnings management and future profitability reveals that earnings management is informational. However, negative a relation between earnings management and future profitability indicates that earnings management is opportunistic.

This study uses data from the OSIRIS database. Four hundred and eighty five (485) companies from the Philippines, Indonesia, Malaysia, Singapore, and Thailand are used as a sample. This study focuses on 2 types of earnings management: (1) accrual earnings management and (2) real earning management. Modified Jones model is used for the accrual earnings management. Real earnings management follows Roychowdury (2006).

The results show that the characteristics of earnings management are not consistent. Real earnings management is informational in Thailand, but opportunistic in Indonesia. Accruals earnings management is informational in the Philippines, but opportunistic in Malaysia. Country factors such as culture may explain the inconsistency of the results in ASEAN.

Abstrak: Penelitian ini mengeksplorasi karakteristik informasional dan oportunistik dari manajemen laba di negara-negara ASEAN. Manajemen laba akan berdampak pada kemampulabaan perusahaan. Hubungan positif antara manajemen laba dan kemampulabaan di masa depan mengungkapkan bahwa manajemen laba bersifat informasional. Sebaliknya, hubungan negatif antara manajemen laba dan kemampulabaan perusahaan di masa depan mengindikasikan bahwa manajemen laba bersifat oportunistik.

Penelitian ini menggunakan data dari database OSIRIS. Empat ratus delapan puluh lima (485) perusahaan dari Filipina, Indonesia, Malaysia, Singapura, dan Thailand digunakan sebagai sampel. Penelitian ini berfokus pada dua jenis manajemen laba: (1) manajemen laba akrual dan (2) manajemen laba riil. Model Modified Jones digunakan untuk manajemen laba akrual. Manajemen laba riil mengikuti model Roychowdury (2006).
\end{abstract}

Corresponding authors. E-mail: indra.kusuma@gadjahmada.edu; d3wi_kusuma@yahoo.co.id

ISSN: 1141-1128

http://www.gamaijb.mmugm.ac.id/ 
Hasil menunjukkan bahwa karakteristik manajemen laba tidak konsisten. Manajemen laba riil bersifat informasional di Thailand, tapi oportunistik di Indonesia. Manajemen laba akrual bersifat informasional di Filipina, tapi oportunistik di Malaysia. Faktor spesifik negara seperti budaya mungkin dapat menjelaskan ketidakkonsistenan hasil di ASEAN.

Keywords: accruals earnings management; ASEAN countries; future profitability; informational; opportunistic; real earnings management 


\section{Introduction}

Earnings management is widely practiced by public companies. In general, the management's objectives in managing earnings are to avoid scrutiny by investors and creditors and seek their own benefit, to get performance-based incentives, to increase stock prices, and to get benefits from government (Cohen et al. 2008).

Therefore, the users of financial statements must be aware of opportunistic earnings management before they make a decision. Opportunistic earnings management makes the current income rise but ignores future profitability. High opportunistic earnings management indicates low quality of earnings (Lo 2008). This low quality of earnings is used by the users to make decisions (Ball and Brown 1968; and Lo 2008).

Earnings management is like a coin with two sides. Besides using earnings management for opportunistic behavior, earnings management is also used for informational purposes. Subramanyam (1996), Siregar and Utama (2008), and Gunny (2009) proved that earnings management has informational purposes. Earnings management with informational purposes carried out by managers to assist financial statement users for better predictions of a company's future performance (Subramanyam 1996; Siregar and Utama 2008; Gunny 2009).

There are two ways to manage earnings. First, earnings are managed through the accrual manipulation without affecting cash flows (accrual earnings management). Secondly, earnings are managed using real activities that affect a company's cash flows (real earnings management). Zang (2007) proved that there are trade offs between accrual earnings management and real earnings management. Management will shift to real earnings manage- ment if accrual earnings management is easily detected.

Zang (2007) showed that managers often practice real earnings management and accrual earnings management simultaneously, but with different proportions. Therefore, Zang (2007) states that because of the substitutive relationship between accrual earnings management and real earnings management, focusing on one type of earnings management exclusively may not fully explain earnings management activities. This research contributes to the literature by including the earnings management nature, opportunistic or informational, and both accrual earnings management and real earnings management.

Leuz (2010) states that each country has its own characteristics, therefore, its accounting practices will vary. Leuz et al. (2003) found various country characteristics, such as investor protection, were associated with earnings management. Countries with poor investor protection have a higher incidence of opportunistic earnings management. ASEAN has ten countries with various characteristics, such as investor protection, legal systems, accounting standards, and history that can create accounting practice differences between countries. Therefore, this study explores the informational and opportunistic characteristics of earnings management in ASEAN countries. A positive relation between earnings management and future profitability reveals that earnings management is informational. However, a negative relation between earnings management and future profitability indicates that earnings management is opportunistic. No relationship between earnings management and future profitability indicates that earnings management is neither opportunistic nor informational, reflecting that it is just a random process. 
The remainder of the paper proceeds as follows. Section II provides a literature review and hypotheses development. Section III discuses the empirical methodology, including the data and sample selection and the variable measurement. The test and result are discussed in Section IV and Section V will conclude.

\section{Literature Review and Hyphoteses Development}

Empirical evidence shows that management manage earnings to avoid reporting earnings below the target (Roychowdury 2006). Management can manage earnings for opportunistic or informational purposes (Subramanyam 1996; Siregar and Utama 2008; and Gunny 2009). Management that manages earnings opportunisticly tends to maximize their bonuses (Scott 2009; Watts and Zimmerman 1986; and Healy 1985).

On the contrary, Demski and Sappington (1978) suggested that management obtain specialized information about future performance, such as new firm strategies, change in firm characteristics, or market conditions, based on their expertise. This information is not communicated directly to the investor because of its cost, so the communication is blocked. The blocked communication can reduce the efficiency of agency contracts (Scott 2009).

One of the solutions to reduce the blockage is earnings management. If a manager announces it in the simple way, the announcement would not be reacted to because of its cost to verify. To solve this problem, a manager will manage earnings to show their inside information with discretionary accruals (Scott 2009). Stocken and Verrecchia
(2004) found that when a manager has some private information which are not captured by a firm's financial reporting system and may manipulate the financial report, at some cost, the manager might not choose the most precise financial system. This earnings management is informational.

A manager will not be so foolish as to report higher earnings than can be reached because the reduction in the future earnings would disappoint the investors who would then punish them through capital and labor market reactions (Barth et al. 1999; and Fee and Hadlock 2003).

Both earnings management purposes have economic consequences for the company. Opportunistic earnings management will cause a negative relationship between earnings management and future profitability. Informational earnings management provides more accurate earnings information and causes a positive relationship between earnings management and future positive profitability (Subramanyam 1996; Siregar and Utama 2008; and Gunny 2009).

Real earnings management is conducted for the opportunistic purpose that real earnings management will improve earnings today but will destroy the company in the long term (Roychowdury 2006; and Cohen et al. 2008) for these reasons:

1. Sales manipulation through increased price discount will make the future cash flow lower because consumers expect discount prices.

2. Sales manipulation through more lenient credit terms make the future cash flow lower because of the difficult the company will have collecting receivables.

3. Overproduction will lead to lower cash flow and higher production costs. 
4. Decreases in discretionary expenses will lead to lower future cash flow and income because of the company's lack of competitiveness.

The proponents of the informational arguments stated that management manages earnings to reduce information blocked (Demski and Sappington 1987). When management has additional information about future performance, he/she cannot give information in the direct statement on financial reporting or firm announcement to prevent the competitor from obtaining their secret information (Demski and Sappington 1990). On other hand, if management does not communicate that information, the ability of investors to make good decisions is reduced. Current net income ability to predict future performance is jammed (Stocken and Verrecchia 2004). Management uses earnings management to give information to reduce asymmetric information between management and investor and increasing the decision-making accuracy (Subramanyam 1996).

Tucker and Zarrowin (2006) found that manager's use of financial reporting discretion is to reveal more information about future earnings and cash flow. Gunny's study (2009) uses U.S. firms as its sample, and proves that real earnings management has a positive relationship with future profitability. Subramanyam (1996) and Siregar and Utama (2008) show that accrual earnings management is positively associate with future profitability.

A positive relationship between earnings management and future profitability is consistent with signaling theory, in which management attempts to give a signal about management's ability to generate better future profit through a joint signal (Graham 2005). Only management that is confident about its future profitability manages earnings. Companies with poor future performance prospects will not use a joint signal, using earnings management, because investors will be disappointed when future profitability is not in accordance with the signals provided by management (Graham 2005).

Based on that, the hypotheses tested in this study are:

$H_{1}$ : Real earnings management is positively associated with future profitability

$H_{2}$ : Accrual earnings management is positively associated with future profitability

From the hypotheses, the framework of this study is described as the Figure 1.

Figure 1. Framework of the Study

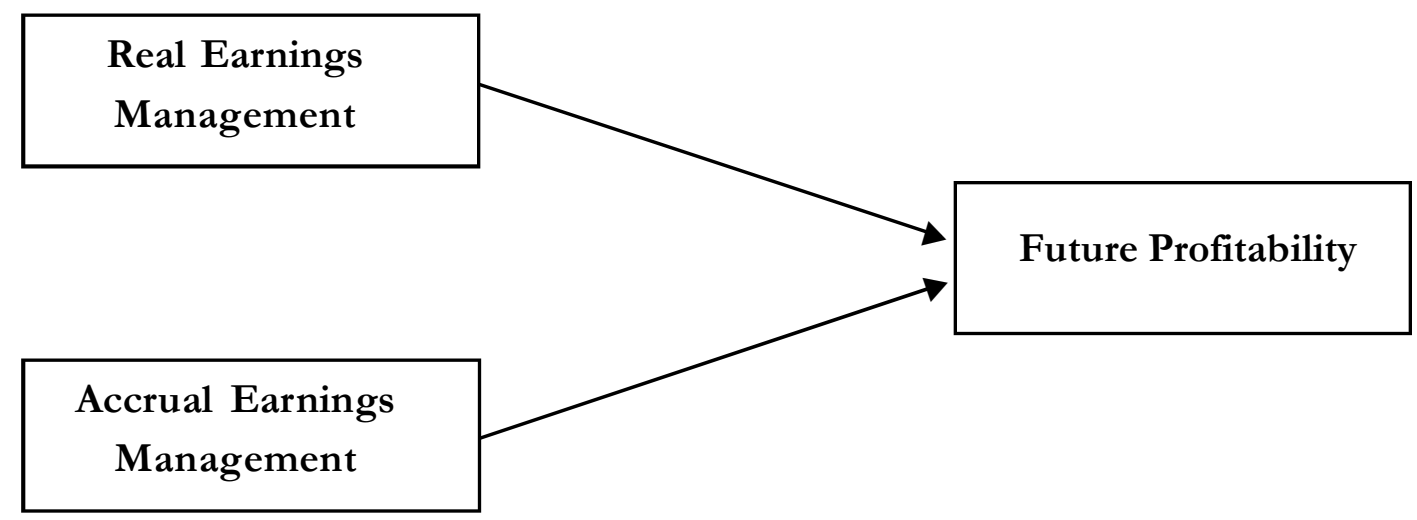


To determine whether the purpose of earnings management is opportunistic or informational, this study investigates the relationship between earnings management, both accrual earnings management and real earnings management, with future profitability. A positive relation between earnings management and future profitability reveals that earnings management is informational. On the other hand, a negative relation between earnings management and future profitability indicates that earnings management is opportunistic. No relationship between earnings management and future profitability reveals neither opportunistic nor informational. It is just a random process.

\section{Research Methods}

\section{Population and Sample}

The population of this study is companies listed on stock exchanges in the ASEAN group of countries. We select ASEAN because these countries have some diversity in terms of investor protection, legal systems, accounting standards, and history. The observation period is 2008 . The data used is the financial data from 2004 to 2009 because the formula requires long-range observations. The sampling method is purposive sampling, which is in the selection of samples based on the following criteria:

1. Listed in stock exchange in five original ASEAN countries (Indonesia, Singapore, Malaysia, Thailand, and the Philippines)

2. Data are available in the OSIRIS database

3. Categorized as a manufacturing company in NAICS 2007 (Primary Code: 31-33)

4. Data from 2004 to 2009 are complete

The public companies in the five ASEAN countries number 3,343 with the distribution as follows: 265 firms in the Philippines, 428 firms in Indonesia, 1,256 firms in Malaysia, 773 firms in Singapore, and 630 firms in Thailand. Only 2,719 firms are available in the OSIRIS database (access date 17/ 9/2010). There are 1,169 manufacturing firms that include in NAICS categorization (TwoDigit Primary Code: 31-33). Uncompleted data

Table 1. Sampling Selection Process

\section{Numbers of Firm}

\begin{tabular}{|c|c|c|c|c|c|c|c|}
\hline No & Criteria & Phillipines & Indonesia & Malaysia & Singapore & Thailand & Total \\
\hline 1 & Public Company & 265 & 428 & 1.256 & 773 & 630 & 3.343 \\
\hline 2 & $\begin{array}{l}\text { Public Company in } \\
\text { OSIRIS }\end{array}$ & 249 & 374 & 966 & 605 & 525 & 2.719 \\
\hline 3 & $\begin{array}{l}\text { Manufacture } \\
\text { Company in } \\
\text { NAICS } 2007 \\
\text { (Primary Code: 31-33) }\end{array}$ & 3) & 154 & 454 & 299 & 221 & 1.169 \\
\hline 4 & Uncomplete data & (34) & $(90)$ & $(263)$ & $(181)$ & $(101)$ & $(659)$ \\
\hline 6 & Outlier data & - & $(2)$ & (8) & (11) & (4) & $(25)$ \\
\hline 7 & Sample firms & 17 & 62 & 193 & 107 & 116 & 485 \\
\hline
\end{tabular}


are 659. From 510 complete firms, there are 485 sample firms because 25 outlier firms are excluded.

\section{Data Collection}

The study used secondary data obtained from the OSIRIS database. This database is a public company database which is produced by Bureau van Dijk Electronic Publishing, SA (Bureau van Dijk Electronic Publishing 2007). ${ }^{1}$

The OSIRIS database provides financial data, ownership data, news, rankings, earnings data, and stock data of public companies, including banks and insurance companies. The database has more than 45,000 companies from 140 countries comprising over 34,000 companies listed on the Stock Exchange and 11,000 companies that are not listed or are no longer listed on the Stock Exchange.

Data retrieved from the database can be trusted because OSIRIS only maintains the highest level quality data of each provider and applies a combination of strict quality control systems. Before the OSIRIS data is delivered to customers, Bureau van Dijk Electronic Publishing also implements a series of quality control measures to check the software and data. The OSIRIS database is updated 12 times per year in the DVD form and 52 times per year in the Internet form. (Bureau van Dijk Electronic Publishing 2007).

\section{Measurement of Variables}

\section{Measurement of real earnings management}

This study used Roychowdhury's earnings management model (Roychowdhury 2006). Proxy for real earnings management is abnormal cash flows from operations (Abn $\mathrm{CFO}$ ), abnormal production cost (Abn prod), and abnormal discretionary expense (Abn Disc Exp). The procedures to calculate the real earnings management are as follows:

1. Calculate abnormal cash flows from operations $(\mathrm{CFO})$

a. Calculate normal operating cash flow from operations as linier function from sales and the change of sales:

$$
\begin{gathered}
\frac{\mathrm{CFO}_{\mathrm{it}}}{\text { Asset }_{\mathrm{i}, \mathrm{t}-1}}=\mathrm{k}_{1 \mathrm{t}} \frac{1}{\text { Asset }_{\mathrm{i}, \mathrm{t}-1}}+\mathrm{k}_{2} \frac{\text { Sales }_{\mathrm{it}}}{\text { Asset }_{\mathrm{i}, \mathrm{t}-1}}+ \\
\mathrm{k}_{3} \frac{\Delta \text { Sales }_{\mathrm{it}}}{\text { Asset }_{\mathrm{i}, \mathrm{t}-1}}+\varepsilon_{\mathrm{it}}
\end{gathered}
$$

b. Calculate abnormal CFO

Abnormal CFO is the difference between actual cash flow and normal cash flow.

$$
\text { Abn } \mathrm{CFO}=\text { Actual } \mathrm{CFO}-\text { Normal CFO }
$$

2. Calculate abnormal production cost

a.Calculate normal production cost that is defined as the sum of cost of good sold (COGS) and the change of inventory.

\footnotetext{
${ }^{1}$ Bureau van Dijk Electronic Publishing, SA (BvDEP) is a privately owned company and business information provider based in Brussels. BvDEP marketing center located in London and has offices around the world, like Amsterdam, Bahrain, Beijing, Bratislava, Brussels, Chicago, Copenhagen, Edinburgh, Frankfurt, Geneva, Lisbon, London, Madrid, Manchester, Mexico City, Milan, Moscow, New York, Paris, Rome, San Francisco, Seoul, Shanghai, Singapore, Stockholm, Sydney, Tokyo, Vienna and Zurich (http:/ / www.bvdinfo.com/About-BvD, accessed 15/12/2010).
} 


$$
\begin{aligned}
\frac{\text { Prod }_{\mathrm{it}}}{\text { Asset }_{\mathrm{i}, \mathrm{t}-1}}= & \mathrm{k}_{1 \mathrm{t}} \frac{1}{\operatorname{Asset}_{\mathrm{i}, \mathrm{t}-1}}+\mathrm{k}_{2} \frac{\text { Sales }_{\mathrm{it}}}{\operatorname{Asset}_{\mathrm{i}, \mathrm{t}-1}}+ \\
& \mathrm{k}_{3} \frac{\Delta \text { Sales }_{\mathrm{it}}}{\operatorname{Asset}_{\mathrm{i}, \mathrm{t}-1}}+\mathrm{k}_{4} \frac{\Delta \text { Sales }_{\mathrm{it}}}{\text { Asset }_{\mathrm{i}, \mathrm{t}-1}}+\varepsilon_{\mathrm{it}} \\
& +
\end{aligned}
$$

b. Calculate abnormal production cost

Abnormal production cost is difference between actual production cost and normal production cost.

Abn Prod Cost $=$ Act Prod Cost - Normal Prod Cost

3. Calculate abnormal discretionary expense a.Calculate normal discretionary expense

$$
\frac{\text { DiscExp }_{i t}}{\text { Asset }_{i, t-1}}=k_{1 \mathrm{t}} \frac{1}{\text { Asset }_{\mathrm{i}, \mathrm{t}-1}}+\mathrm{k}_{2} \frac{\text { Sales }_{\mathrm{it}}}{\text { Asset }_{\mathrm{i}, \mathrm{t}-1}}+\varepsilon_{\mathrm{it}}
$$

b.Calculate abnormal discretionary expense Abnormal discretionary expense is difference between discretionary expense and normal discretionary expense

Abn Disc Exp = Act Disc Exp -

$$
\text { Normal Disc Exp }
$$

\section{Measurement of Real Earnings Manage-} ment (REM)

Real earnings management is calculated by adding the standardized abnormal cash flows from operations (CFO Abn), abnormal production cost (Abn Prod Cost), and abnormal discretionary expenses (Abn Disc Exp.). Before added, abnormal CFO and Abn Exp Disc is multiplied by -1 . This is done because the three real earnings management proxies have different directions. Abn Disc Exp and Abn
CFO have negative directions, while Abn Prod Cost has a positive direction (Cohen and Zarowin 2008)

\section{Explanation}

$$
\begin{aligned}
& \mathrm{CFO}_{\mathrm{t}} / \text { Assets }_{\mathrm{t}-1} \quad=\text { operational cash } \\
& \text { flow divided by to- } \\
& \text { tal assets } \\
& 1 \text { Assets }_{\mathrm{t}-1} \quad=\text { intercept divided by } \\
& \text { total assets } \\
& \text { Sales }_{\mathrm{t}-1} / \text { Assets }_{\mathrm{t}-1} \quad=\text { net sales divided by } \\
& \text { total assets } \\
& \Delta \text { Sales }_{\mathrm{t}-1} / \text { Assets }_{\mathrm{t}-1}=\text { change of net sales } \\
& \text { divided by total as- } \\
& \text { sets } \\
& \mathrm{COGS}_{\mathrm{it}} / \text { Assets }_{\mathrm{t}-1}=\text { cost of good sold } \\
& \text { divided by total as- } \\
& \text { sets } \\
& \Delta \mathrm{INVit}_{1} / \text { Assets }_{\mathrm{t}-1}=\text { change of inventory } \\
& \text { divided by total as- } \\
& \text { sets } \\
& \operatorname{Prod}_{\mathrm{t}} \quad=\text { production cost } \\
& \operatorname{DiscExp}_{\mathrm{t}} \quad=\text { discretionary ex- } \\
& \text { pense } \\
& =\text { error }
\end{aligned}
$$

\section{Measurement of accrual earnings management}

This study used discretionary accruals for the accrual earnings management proxy. Discretionary accrual is measured with Modified Jones Model (Dechow et al. 1995).

1. Calculate Total Accrual

$$
\text { TACC }_{\text {it }}=\mathrm{EBXT}_{\text {it }}-\mathrm{CFO}_{\text {it }}
$$

\section{Estimate total accrual}

Total accrual (TACC) is estimated by following regression equation: 


$$
\begin{aligned}
\frac{\text { TACC }_{\text {it }}}{\mathrm{TA}_{\mathrm{i}, \mathrm{t}-1}}= & \alpha_{1 \mathrm{t}}\left(\frac{1}{\mathrm{TA}_{\mathrm{i}, \mathrm{t}-1}}\right)+ \\
& \alpha_{2}\left(\frac{\Delta \mathrm{REV}_{\mathrm{it}}-\Delta \mathrm{REV}_{\mathrm{it}}}{\mathrm{TA}}\right)+ \\
& \alpha_{3}\left(\frac{\mathrm{PPE}_{\mathrm{it}-\mathrm{t}}}{\mathrm{TA}_{\mathrm{i}, \mathrm{t}-1}}\right)+\mathrm{e}
\end{aligned}
$$

3. Calculate non discretionary accrual

Using regression coefficient, non discretionary accruals (NDACC) is

$$
\begin{aligned}
\text { NDACC }_{\mathrm{it}}= & \alpha_{1 \mathrm{t}}\left(\frac{1}{\mathrm{TA}_{\mathrm{i}, \mathrm{t}-1}}\right)+ \\
& \alpha_{2}\left(\frac{\Delta \mathrm{REV}_{\mathrm{it}}-\Delta \mathrm{REV}_{\mathrm{it}}}{\mathrm{TA}_{\mathrm{i}, \mathrm{t}-1}}\right)+ \\
& \alpha_{3}\left(\frac{\mathrm{PPE}_{\mathrm{it}}}{\mathrm{TA}_{\mathrm{i}, \mathrm{t}-1}}\right) \ldots \ldots \ldots \ldots \ldots . . .(3)
\end{aligned}
$$

4. Discretionary accrual

Discretionary accrual (DA) can be calculated with formula:

$$
\text { DACC }_{i t}=\left(\frac{\mathrm{TACC}_{\mathrm{it}}}{\mathrm{TA}_{\mathrm{i}, \mathrm{t}-1}}\right)-\mathrm{NDACC}_{\mathrm{it}}
$$

\section{Explanation}

DACC $_{\mathrm{it}}=$ discretionary accruals

NDACC $_{\text {it }}=$ non discretionary accruals

TACC $_{\text {it }}=$ total accruals

$\mathrm{TA}_{\mathrm{it}-1}=$ total asset

EBXT $_{\text {it }}=$ earnings before extraordinary item and tax

$\mathrm{CFO}_{\text {it }}=$ operational cash flow

$\Delta \operatorname{Rev}_{\mathrm{t}}=$ change of revenue
$\mathrm{PPE}_{\mathrm{t}} \quad=$ property, plant, and equipment

$\Delta \mathrm{Rec}_{\mathrm{t}}=$ change of receivable

$\mathrm{e}=$ error

\section{Measurement of future profitability}

According to Subramanyam (1996) and Siregar and Utama (2008), future profitability can be measured by calculating the change in earnings one year ahead divided by total assets at beginning of year $\left(\Delta \mathrm{NI}_{\mathrm{t}+1} / \mathrm{TA}_{\mathrm{t}}\right)$

$$
\Delta \mathrm{NI}_{\mathrm{t}+1}=\mathrm{NI}_{\mathrm{t}+1}-\mathrm{NI}_{\mathrm{t}}
$$

This study used $\Delta N I_{t+1}$ because Subramanyam (1996) argued that $\Delta \mathrm{NI}_{t+1}$ is the most appropriate future profitability measurement.

\section{Explanation}

$\mathrm{NI}_{\mathrm{t}+1}=$ one-year-ahead net income

$\Delta \mathrm{NI}_{\mathrm{t}+1}=$ one-year-ahead change in net income

$\mathrm{NI}_{\mathrm{t}}=$ net income

$\mathrm{TA}_{\mathrm{t}}=$ total asset

\section{Control variables}

This study uses two control variables, firm size and growth opportunity. The proxy of firm size is the natural logarithm of assets (Ln Asset). Price earnings ratio is the proxy for growth opportunity.

\section{Results}

Table 2 provides the descriptive statistics for the sample firms. Sample data consists of 485 firms with 17 Philippines firms, 62 Indonesian firms, 183 firms from Malaysia, 107 firms from Singapore, and 116 Thailand firms. The statistics of the mean real earnings management show that real earnings 
management is aggressive in Singapore, Thailand, and Malaysia compared to the Philippines and Indonesia. The mean of accrual earnings management is high in the Philippines and Indonesia compared to Malaysia, Singapore, and Thailand. This evidence proves that real earnings management and accrual earnings management have a substitutive relationship. This finding corroborates Zang (2007), Cohen et.al's study (2008) and Gunny's study (2009). The incidence of ac- crual earnings management is higher in countries that have weak investor protection than in the countries that have strong investor protection. On the other hand, the incidence of real earnings management is higher in countries that have strong investor protection than in the countries that have weak investor protection. Because of the substitutive relationship between accrual earnings management and real earnings management, we must observe both of them. Focusing on one type of

Table 2. Descriptive Statistic

\begin{tabular}{|c|c|c|c|c|c|c|c|}
\hline & Region & Mean & Median & Minimum & Maximum & $\mathbf{N}$ & Std. Deviation \\
\hline \multirow[t]{5}{*}{ Philippines } & REM & -0.0004 & 0.5482 & -5.14 & 3.42 & 17 & 2.15920 \\
\hline & $A E M$ & 1.1968 & 0.8059 & -7.86 & 9.09 & 17 & 3.54037 \\
\hline & LnAssets & 11.9444 & 11.7968 & 6.70 & 15.78 & 17 & 1.98629 \\
\hline & PER & 19.7735 & 7.2400 & 1.97 & 170.61 & 17 & 40.79785 \\
\hline & $\Delta N I_{t+1}$ & -0.0161 & 0.0090 & -0.68 & 0.18 & 17 & 0.18044 \\
\hline \multirow[t]{5}{*}{ Indonesia } & REM & -0.0874 & 0.6771 & -7.72 & 2.77 & 62 & 2.33691 \\
\hline & $A E M$ & 0.0904 & 0.860 & -0.10 & 0.40 & 62 & 0.10456 \\
\hline & LnAssets & 11.3059 & 11.1767 & 7.72 & 15.60 & 62 & 1.58809 \\
\hline & PER & 16.9635 & 7.6150 & 1.41 & 252.45 & 62 & 35.41357 \\
\hline & $\Delta N I_{t+1}$ & 0.0362 & 0.0419 & -0.68 & 0.27 & 62 & 0.13754 \\
\hline \multirow[t]{5}{*}{ Malaysia } & $R E M$ & 0.1024 & 0.1695 & -6.42 & 6.39 & 183 & 1.91495 \\
\hline & $A E M$ & -0.0157 & -0.0264 & -0.24 & 0.39 & 183 & 0.10433 \\
\hline & LnAssets & 11.4377 & 11.2750 & 8.87 & 15.96 & 183 & 1.26468 \\
\hline & PER & 16.1985 & 7.1800 & 0.72 & 651.30 & 183 & 49.52864 \\
\hline & $\Delta N I_{t+1}$ & -0.0045 & -0.0041 & -0.16 & 0.14 & 183 & 0.04563 \\
\hline \multirow[t]{5}{*}{ Singapore } & $R E M$ & 0.2347 & 0.4071 & -3.79 & 4.88 & 107 & 1.47291 \\
\hline & $A E M$ & 0.0837 & 0.0929 & -0.57 & 0.65 & 107 & 0.22292 \\
\hline & LnAssets & 11.7832 & 11.5356 & 9.28 & 16.27 & 107 & 1.36095 \\
\hline & PER & 14.6057 & 6.8200 & 0.58 & 297.55 & 107 & 33.31947 \\
\hline & $\Delta N I_{t+1}$ & -0.0090 & -0.0064 & -0.19 & 0.15 & 107 & 0.06117 \\
\hline \multirow[t]{5}{*}{ Thailand } & REM & 0.1232 & 0.1882 & -6.14 & 5.23 & 116 & 1.83147 \\
\hline & $A E M$ & 0.0540 & 0.0477 & -0.24 & -0.35 & 116 & 0.07284 \\
\hline & LnAssets & 11.2712 & 11.1210 & 8.85 & 15.15 & 116 & 1.24867 \\
\hline & PER & 14.3248 & 6.7700 & 0.70 & 213.92 & 116 & 27.28886 \\
\hline & $\Delta N I_{t+1}$ & 0.0035 & 0.0047 & -0.37 & 0.19 & 116 & 0.06738 \\
\hline Total & & & & & & 485 & \\
\hline
\end{tabular}


earnings management exclusively may not fully explain earnings management activities (Zang 2007).

The mean of future profitability $\left(\Delta \mathrm{NI}_{\mathrm{t}+1}\right)$ is higher in Indonesia and Thailand compared to Malaysia, the Philippines, and Singapore. The economic crisis in the U.S. influenced Indonesia and Thailand, so profitability in 2008 was worse. By 2009, the profitability was getting better. Indonesia and Thailand have positive prospects for future profitability. On the other hand, the U.S. economic crisis did not influence Malaysia, the Philippines, and Singapore. They have negative prospects for future profitability because, on the average, the companies' profitability in 2009 was worse than in 2008 .

Firms in five ASEAN countries are of the same size. The Philippine has higher growth opportunities compared to other countries that showed by the highest PER.
From Table 3 we can conclude that accrual earnings management in the Philippines is informational, but real earnings management does not have a relationship with future profitability. Firms in the Philippines manage earnings to give adequate information to the shareholder. Firms' managed earnings indicate a firm has made a profit and they still have a good future profitability. The real earnings management that does not have any relation with future profitability indicates that the real earnings management in the Philippines is not strategically planned by managers to create better future profitability. In addition, in the Philippines, a firm's future profitability is influenced by firm size. Bigger firms have prospects of higher future profitability.

By contrast, real earnings management in Thailand is informational, but future profitability is not influenced by accrual earnings management. Thailand's firms manage real

Table 3. Regression Result of Hipotheses 1 and 2

\begin{tabular}{lccccc}
\hline $\begin{array}{l}\text { Country } \\
\text { Variable }\end{array}$ & Philippines & Indonesia & Malaysia & Singapore & Thailand \\
\hline Constanta & -0.582 & -0.315 & 0.047 & -0.023647 & 0.008 \\
& $(0.013)$ & $(0.008)$ & $(0.125)$ & $(0.6779)$ & $(0.895)$ \\
REM & 0.024 & $\mathbf{- 0 . 0 1 9} * *$ & 0.001 & 0.004041 & $\mathbf{0 . 0 0 8} * *$ \\
& $(0.164)$ & $\mathbf{( 0 . 0 0 7 )}$ & $(0.547)$ & $(0.3698)$ & $\mathbf{( 0 . 0 4 8 )}$ \\
AEM & $\mathbf{0 . 0 2 6} * *$ & -0.136 & $\mathbf{- 0 . 0 7 3} * *$ & -0.044262 & -0.006 \\
& $\mathbf{( 0 . 0 1 8 )}$ & $(0.366)$ & $\mathbf{( 0 . 0 3 0 )}$ & $(0.0792)$ & $(0.947)$ \\
Ln Assets & $\mathbf{0 . 0 4 4} * *$ & $\mathbf{0 . 0 3 1} * *$ & -0.004 & 0.001336 & 0.000 \\
& $\mathbf{( 0 . 0 2 3 )}$ & $\mathbf{( 0 . 0 0 3 )}$ & $(0.101)$ & $(0.7671)$ & $(0.942)$ \\
PER & 0.001 & $\mathbf{0 . 0 0 1} * *$ & 0.001 & 0.00008 & 0.001 \\
& $(0.601)$ & $\mathbf{( 0 . 0 4 5 )}$ & $(0.007)$ & $(0.447)$ & $(0.893)$ \\
\hline
\end{tabular}


activities to show that the firm's future profitability will be better and the investor can trust the firm's performance. The real earnings management in Thailand is a firm's strategic planning to get better profit and for investor wealth. In Thailand, future profitability is not influenced by firm size. The pro-fitability of big firms is not always better than that of small firms. Investors can be confident about investing in both of them. Further, the future profitability is not influenced by growth opportunity. The better future profitability is not because of the better growth opportunity, but because of the manager's strategic planning.

In Thailand, investors can trust that the price discount and more lenient credit terms are not to accelerate the timing of sales, that increasing of production is not to report the lower cost of goods sold, and that reducing discretionary expenses, such as advertising, research and development, and SG\&A expenses, are not to reduce the expense to boost current period earnings. All of the manager's action are a part of strategic planning and the firm will not get worse in future. This finding conradicts Roychowdury's argument (Roychowdury 2006). He argues that managers will manage earnings through real activity, like accelerating the timing of sales through increased price discount and more lenient credit terms, reporting lower cost of goods sold through increased production, and decreasing discretionary expenses to boost current period earnings. All of that real activity will worsen the firm's future profitability (Roychowdury 2006).

In Indonesia, real earnings management is opportunistic, but accrual earnings management does not have a relationship with future profitability. These findings do not support Siregar and Utama's findings (Siregar and Utama 2008). They found that accrual earnings management in Indonesia is informational. Managers give information about insights to investors so that the asymmetricity of information is reduced and the investor can make good decisions (Siregar and Utama 2008). But in this study, accrual earnings management does not have a relationship with future profitability, so the managers' actions do not give better information but are for their own benefit. Specificially, real earnings management in Indonesia is opportunistic. Managers will manage earnings through real activity, such as acceleration of timing of sales through increased price discount and more lenient credit terms, reporting lower cost of goods sold through increased production, and decreasing discretionary expense to boost current period earnings. In the current year, the firms has good profits but all of that real activity will worsen the firm's future profitability. Investors must be careful with managers' actions. 'This finding supports Roychowdury's argument (Roychowdury 2006). Furthermore, future profitability in Indonesia is influenced by firm size and growth opportunity.

Accrual earnings management in Malaysia is opportunistic, but real earnings management does not have any relationship with future profitability. Malaysian firms manage earnings to get themselves benefits but ignore the investors' interests. This finding supports the Leuz's study (2010). Leuz finds that Malaysia has strict legal protection for investors but it is weak in practice. Auditors in Malaysia must be aware of this fact. They must protect the investors from managerial fraud. On the other side, investors must be careful with managers' actions in accrual manipulations and real activities. Although the government protects investors with tight regulation, in practice it is not always implemented. 
Future profitability in Singapore is not influenced by real earnings management, accrual earnings management, firm size, and growth opportunity. Singapore's firms manage earnings not to give more information to investor. This finding is not consistent with the previous studies (Subramanyam 2006 and Gunny 2009). The economic crisis that struck the U.S. and some other countries may have had a role to this phenomena.

Country factors such as culture may explain the inconsistencies of the result across the ASEAN countries. Some diversity in terms of investor protection, legal systems, accounting standards, and history among ASEAN countries will create variations in accounting practices, including earnings management. Investors must be careful when they choose the country where they will invest money because every country has different characteristics. They must scrutinize managers' actions because sometimes managers manage earnings to benefit themselves and not investors' interest.

\section{Conclusion}

The results show that the characteristics of earnings management are not consistent. Accrual earnings management in the Philippines is informational, but real earnings management does not have a relationship with future profitability. Managers in the Philippines manage earnings through an accounting policy to give adequate information to the shareholder, so they do not make a bad decision-making. The real earnings management, which does not have any relation with future profitability, indicates that the real earnings management in the Philippines is not strategically planned by manager to create better profitability in the future. By contrast, real earnings management in Thailand is informa- tional, but future profitability is not influenced by accrual earnings management. Thai managers manage real activities to show that the firm's future profitability will be better and the investor can trust the firm's performance. The real earnings management in Thailand is part of a firm's strategic planning to get better profit and for investor wealth.

In Indonesia, real earnings management is opportunistic. However, accrual earnings management does not have a relationship with future profitability. The managers' actions do not give better information but are to benefit themselves. Real earnings management in Indonesia is opportunistic. Managers manage earnings through real activity, like accelerating the timing of sales through increased price discount and more lenient credit terms, reporting lower cost of goods sold through increased production, and decreasing discretionary expenses to boost current period earnings. Accrual earnings management in Malaysia is opportunistic, but real earnings management does not have any relationship with future profitability. Malaysian firms manage earnings for their own benefit and ignore the investors' wealth. Future profitability in Singapore is not influenced by real earnings management, accrual earnings management, firm size, and growth opportunity. Singapore's management manages earnings so as not to give more information to investor.

Country factors such as culture may explain the inconsistencies of the results across ASEAN. Some diversities in terms of investor protection, legal systems, accounting standards, and history among ASEAN countries cause the variation in accounting practices, including earnings management. The different levels of impact of the economic crisis in 2008 among ASEAN countries causes the inconsistencies in the earnings management practices too. 
This study has several limitations. First, it only uses 2008 as the observation year. Therefore, we must be careful when interpreting this result because 2008 was the year of the U.S. economic crisis which had an impact on ASEAN countries' economies. A sensitivity study to explore whether there are differences crisis and non-crisis periods could not be carried out because of data limitations. Second, the sample was limited because of the unavailability of complete data on the OSIRIS database.
This study did not observe factors that may affect the informational of accrual earnings management and real earnings management. In addition, this study only uses a oneyear period during the world economic crisis. Therefore, future studies can include factors that may affect the informational purposes of accrual earnings management and real earnings management and use a longer period observation.

\section{References}

Ball, R., and P. Brown. 1968. An empirical evaluation of accounting income numbers. Journal of Accounting Research 6 (2): 159-178.

Barth, M. E., J. A. Elliot, and M. W. Finn. 1999.Market rewards associated with patterns of increasing earnings. Journal of Accounting Research (Autumn):387-413.

Bureau van Dijk Electronic Publishing. 2007.OSIRIS: Data Guide.Singapore: Bureau van Dijk Electronic Publishing.

Cohen, D., A. Dey, and T. Lys. 2008. Real and accrual-based earnings management in the pre- and postsarbanes oxley periods. Accounting Review 83: 757-787.

Cohen, D., and P. Zeroing. 2008. Economics consequences of real and accrual based earnings management activities. Working Paper. New York University.

Dechow, P. M, R. G. Sloan, and A. P. Sweeney. 1995. Detecting earnings management. Accounting Review 70 (2): 193-225.

Demski, J., and D. E. M. Sappington. 1987. Delegated expertise. Journal of Accounting Research (Spring): 68-89.

Demski, J., and D. E. M. Sappington. 1990. Fully revealing income measurement. The Accounting Review (April): 363-383.

Fee, C. E., and C. J. Hadlock. 2003. Raids, rewards, and reputations in the market for managerial talent. The Review Financial Studies 16 (4) (Winter): 1315-1357

Gunny, K. 2009. The relation between earnings management using real activities manipulation and future performance: Evidence from meeting earnings benchmarks. Working Paper. University of Colorado.

Healy, P. M. 1985. The effect of bonus schemes on accounting decisions. Journal of Accounting and Economics (April): 85-107.

Leuz, C. 2010. Different approaches to corporate reporting regulation: How juridictions differ and why. Accounting and Business Research 40 (3): 229-256. International Accounting Policy Forum. 
Leuz, C., D. Nanda, and P. D. Wysocki. 2003. Earnings management and investor protection: An international comparison. Journal of Financial and Economics 69: 505-527.

Lo, K. 2008. Earnings management and earnings quality. Journal of Accounting and Economics 45: 350-357.

Roychowdhury, S. 2006. Earnings management through real activities manipulation. Journal of Accounting and Economics 42: 335-370.

Scott, W. R. 2009. Financial Accounting Theory (5 ${ }^{\text {th }}$.). Ontario: Pearson Canada Inc.

Siregar, S. V., and S. Utama. 2008. Type of earnings management and the effect of ownership structure, firm size, and corporate-governance practices: Evidence from Indonesia. International Journal of Accounting 43: 1-27.

Stocken R. K., and D. E. M. Verrecchia. 2004. Financial reporting system choice and disclosure management. The Accounting Review (October): 1181-1203

Subramanyam, K. R. 1996. The pricing of discretionary accruals. Journal of Accounting and Economics 22: 249-281.

Subramanyam, K. R., and J. Jeweled. 2009. Financial Statement Analysis (10 ${ }^{\text {th }}$ ed.). Singapore: McGraw-Hill

Tucker, J. W., and P. A. Zarowin. 2006. Does income smoothing improve earnings informativeness? The Accounting Review 81 (1): 251-270.

Watts, R. L., and J. L. Zimmerman.1986. Positive Accounting Theory. New Jersey: Prentice-Hall International Inc.

Zang, A. 2006. Evidence on the tradeoff between real manipulation and accrual manipulation. Working Paper. University of Rochester.. 